\title{
Telenursing in care, education and management in Latin America and the Caribbean: an integrative review
}

\author{
Teleenfermería en el cuidado, educación y gestión en América Latina y el Caribe: revisión integrativa \\ Tele enfermagem no cuidado, educação e gestão na América Latina e o Caribe: revisão integrativa
}

\section{Maria Cecilia Toffoletto' \\ ORCID: 0000-0003-3484-6250 \\ Jorge David Ahumada Tello" \\ ORCID: 0000-0003-3069-5184}

'Universidad de Las Americas. Santiago, Chile. "Universidad Tecnológica de Chile INACAP. Rancagua, Chile.

How to cite this article:

Toffoletto MC, Ahumada-Tello JD. Telenursing in care, education and management in Latin America

and the Caribbean: an integrative review. Rev Bras Enferm. 2020;73(Suppl 5):e20190317. doi: http://dx.doi.org/10.1590/0034-7167-2019-0317

\section{Corresponding author:}

Maria Cecilia Toffoletto

E-mail:mtoffoletto@udla.cl

EDITOR IN CHIEF: Dulce Barbosa ASSOCIATE EDITOR: Antonio José de Almeida Filho

Submission: 04-12-2019

Approval: 06-15-2020

\begin{abstract}
Objective: Analyze the knowledge generated about telenursing related to the roles of nurses (care, education and management) in Latin America and the Caribbean, based on scientific evidence. Methods: Integrative review, for the years 2009 to 2019, in scientific databases from Latin America and the Caribbean. Twelve articles were selected. Results: Nine studies focused on care and three on education. The information and communication technology used in the studies was telephony directed toward non-communicable diseases. There were concerns about the remote communication process. With respect to education, two focused on educating health teams and one on educating patients. Conclusion: It is necessary to conduct studies on telenursing that generate changes in care practices, explore information and communication technology resources and provide communication training focused on this new care model.
\end{abstract}

Descriptors: Telenursing; Nursing Informatics; Patient Care; Education; Health Management.

\section{RESUMEN}

Objetivo: Analizar el conocimiento producido sobre teleenfermería en relación a los roles (cuidado, educación y gestión) de los enfermeros de América Latina y el Caribe a partir de la evidencia científica. Métodos: Revisión integrativa, considerándose período desde 2009 al 2019, en bases científicas de América Latina y el Caribe. Fueron seleccionados 12 artículos. Resultados: Se encontraron nueve estudios con foco en el cuidado y tres sobre educación. La tecnología de información y comunicación utilizada en los estudios fue la telefonía, aplicada para consultas sobre enfermedades no transmisibles. Se evidenció preocupación por el proceso de comunicación a distancia. Dos de los estudios sobre educación apuntan a educación del equipo de salud, y el tercero al paciente. Conclusión: Es necesario desarrollar investigaciones en teleenfermería que generen cambios en la práctica asistencial y exploren los recursos tecnológicos de información y comunicación; y una formación comunicacional específica enfocada en esta nueva modalidad de cuidado.

Descriptores: Teleenfermería; Informática Aplicada a la Enfermería; Atención al Paciente; Educación; Gestión en Salud.

\section{RESUMO}

Objetivo: Analisar o conhecimento produzido sobre teleenfermagem com relação aos papéis (cuidado, educação e gestão) dos enfermeiros na América Latina e no Caribe com base em evidências científicas. Métodos: Revisão integrativa, considerando o período de 2009 a 2019, em bases científicas da América Latina e do Caribe. Foram selecionados 12 artigos. Resultados: Foram encontrados nove estudos com foco no cuidado e três na educação. A tecnologia de informação e comunicação utilizada nos estudos foi a telefonia, aplicada para consultas sobre doenças não transmissíveis. Foi demonstrada preocupação com o processo de comunicação remota. Dois dos estudos sobre educação apontam para a educação da equipe de saúde, e o terceiro para o paciente. Conclusão: É necessário desenvolver pesquisas em teleenfermagem que gerem mudanças na prática do cuidado e explorem recursos tecnológicos de informação e comunicação; além de uma formação específica em comunicação, com foco nessa nova modalidade de cuidado.

Descritores: Teleenfermagem; Informática em Enfermagem; Assistência ao Paciente; Educação; Gestão em Saúde. 


\section{INTRODUCTION}

In Latin America and the Caribbean, a strong emphasis has been placed on expanding healthcare coverage, especially to ensure care for rural and urban-marginal populations and people living in remote and difficult-to-access regions ${ }^{(1)}$.

In this sense, telehealth has been an innovative proposal since, among various benefits, it enables the optimization of specialized human resources for remote populations or those that have problems accessing health care or lack the opportunity ${ }^{(2)}$.

According to the Pan American Health Organization (PAHO), telehealth entails the delivery of health services using information and communication technologies (ICT), where distance is a limitation for health services. In developing countries, telehealth is important for improving health systems, since it enhances the supply of services, streamlines diagnoses and treatment, overcomes geographical distances, improves quality, and contributes to professional training ${ }^{(3)}$.

The term started to be used widely, allowing other activities in the health field to be grouped together and incorporating the idea of interdisciplinarity ${ }^{(2)}$. Since 2008 , the International Council of Nurses (ICN) consider telenursing to be a service that enables nurses to administer care to rural or remote populations, maintain effective communication with patients with non-communicable diseases, intervene effectively in promotion and education on healthy living and self-care, among others ${ }^{(4)}$.

Despite its newness, telenursing in Europe and the United States is very developed and is used in various types of health care. The advances are related to the follow-up of postsurgical patients who have difficulties getting to health centers, monitoring of chronic patients, telephone support and home patient care ${ }^{(5)}$.

In Latin America and the Caribbean, Internet-based healthcare solutions are seen as a possible means for overcoming inequality and improving people's quality of life in areas such as health promotion, prevention, diagnosis, treatment, management, information and research ${ }^{(6)}$.

In relation to telenursing in Latin America and the Caribbean, the present challenge is its positioning, to promote care that uses what most people have at hand, such as access to the Internet, computers and mobile devices. Since the nursing praxis is a broad concept that encompasses various roles in different fields of action, including care, education and management, telenursing becomes a tool that enables covering all these activities, while maintaining an open channel between nurses and patients ${ }^{(7)}$.

In an effort learn about these telenursing activities in Latin America and the Caribbean, not only from the perspective of the use of the technologies, but to strengthen professional roles through the use of these tools as an added value, this integrative review seeks to analyze the knowledge generated about telenursing related to the roles (care, education and management) of nurses in Latin America and the Caribbean, based on scientific evidence.

\section{OBJECTIVE}

Identify the knowledge generated about telenursing related to the roles of nurses (care, education, and management) in Latin America and the Caribbean based on scientific evidence.

\section{METHODS}

This is an integrative review that provides a summary of the knowledge produced on the topic, and recognizes, in turn, the need for information for future studies ${ }^{(8)}$.

The specific time frame of the search was 2009 to 2019. The choice of the time cohort was based on the terminology of telenursing considered by ICN from 2008 to the present, and the guiding question was:

What knowledge has been generated about telenursing related to the roles of nurses (care, education, and management) in Latin America and the Caribbean, based on scientific evidence?

The roles were established in accordance with the ICN which defines nursing as the "autonomous and collaborative care of individuals of all ages, families, groups and communities, sick or well and in all settings. Nursing includes the promotion of health, prevention of illness, and the care of ill, disabled and dying people." Management is also viewed as participation in shaping health policy and health systems management, and education as imparting teachings on health care and providing training ${ }^{(9)}$.

The criteria adopted for selecting the articles were: the categories of original articles, review articles, case studies, letters to the editor and editorials, in free-access full text, published in Portuguese, English and \or Spanish, between the years of 2009 and 2019, and conducted by nurses from countries in Latin America and the Caribbean. Exclusion criteria: duplicate reports.

The search was performed in the portal of the Latin American and Caribbean Center on Health Sciences Information (BIREME) and the databases of SciELO (Scientific Electronic Library Online), which were chosen since they have publications from Latin America and the Caribbean, thereby meeting the objective of the study.

The keywords used for gathering the texts were selected through the health terminology (DeCS) of the Virtual Health Library (BIREME), as follows: Telenursing," "Telenursing and nursing informatics", “Telenursing and patient care","Telenursing and education","Telenursing and health management" and "Telenursing and delivery of health care".

A total of 1,231 (BIREME: 1,184, SciELO: 47) articles were obtained, of which 1,168 were excluded for not meeting the inclusion criteria and 43 due to repetition. After reading the 20 selected articles, eight were excluded because they were not on the topic of telenursing with respect to nursing roles. (Figure 1)

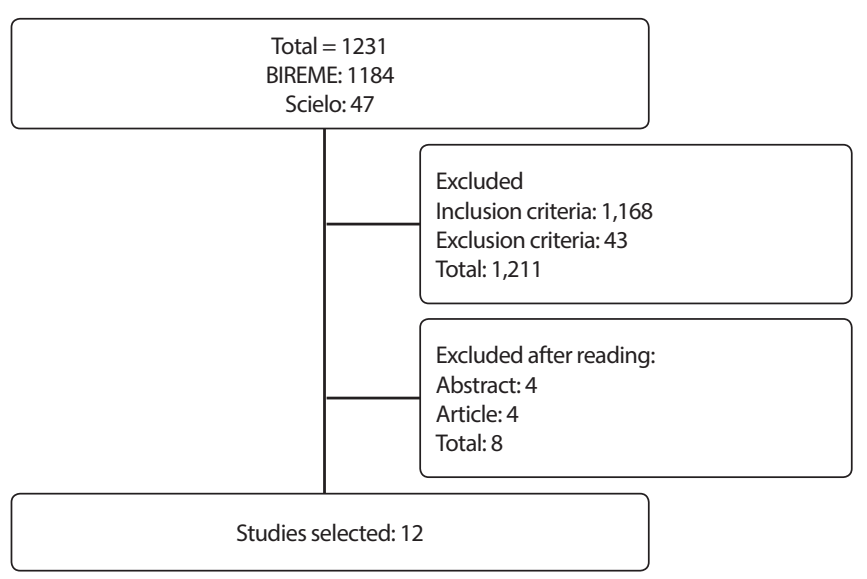

Figure 1- Flowchart of the studies selected 


\section{RESULTS}

Of the total 12 studies selected, $66.7 \%$ (8) were original articles, followed by $25 \%$ (3) that were review articles and one case study. $66.7 \%$ (8) were studies conducted by nurses from Brazil, one from Chile, one from Colombia and one from Costa Rica. Apart from articles in Portuguese and/or Spanish, 75\% (9) were published in English. 75\% (9) of the studies were related to care and no studies were found in regard to the management role. Of the nine (75\%) studies that focused on care, two (22.2\%) were quasi-experimental, two (22.2\%) were qualitative, two (22.2\%) were quantitative and three (33.3\%) were review-based in terms of design. (Chart 1)

Chart 2 presents the objectives and main results from each study. The studies were related to telephony as a remote information and communication technology, targeting non-communicable diseases. There were also concerns about the remote communication process in providing care to people. With regard to education, of the three studies selected, two focused on the education of health teams and one on the education of patients. As technology, the studies used video conferencing, teleconsultations and online courses.

Chart 1 - Characteristics of the studies by year, country, design, number of participants, languages and nursing role (care, education and management). Databases: BIREME, SciELO

\begin{tabular}{|c|c|c|c|c|}
\hline Title/Year & Country & Design/Number of participants & Languages & Role \\
\hline $\begin{array}{l}\text { Article 1: Evaluation of the training } \\
\text { of nurses in basic health units } \\
\text { through telenursing; } 2014^{(10)}\end{array}$ & Brazil & $\begin{array}{l}\text { Descriptive study with a qualitative approach, with a sample } \\
\text { of } 17 \text { nurses from primary care units in the state of Minas } \\
\text { Gerais, Brazil. }\end{array}$ & $\begin{array}{l}\text { Portuguese } \\
\text { English }\end{array}$ & Education \\
\hline $\begin{array}{l}\text { Article 2: Effect of a tele-care model } \\
\text { on self-management and metabolic } \\
\text { control among patients with type } 2 \\
\text { diabetes in primary care centers in } \\
\text { Santiago, Chile; } 2010^{(11)}\end{array}$ & Chile & $\begin{array}{l}\text { Quasi-experimental design (baseline measurement, } 8 \text { and } \\
15 \text { months) with diabetes mellitus } 2 \text { patients who attend the } \\
\text { Cardiovascular Health Program of a municipality in Santiago, } \\
\text { Chile. } \\
\text { The intervention group consisted of } 206 \text { patients and the } \\
\text { control group of } 226 \text { patients. }\end{array}$ & Spanish & Care \\
\hline $\begin{array}{l}\text { Article 3: Imaginative construction } \\
\text { of care: the nursing professional } \\
\text { experience in a remote care service; } \\
2012^{(12)}\end{array}$ & Chile & $\begin{array}{l}\text { Qualitative study which used Grounded Theory and } \\
\text { Symbolic Interactionism methodology for the theoretical } \\
\text { framework. The participants were eight health professionals, } \\
\text { nurses and midwives from the Salud Responde remote care } \\
\text { service in Chile. }\end{array}$ & $\begin{array}{l}\text { Portuguese } \\
\text { English } \\
\text { Spanish }\end{array}$ & Care \\
\hline $\begin{array}{l}\text { Article 4: Effectiveness of an } \\
\text { educational program in nursing in } \\
\text { the self-care of patients with heart } \\
\text { failure: randomized controlled trial; } \\
2012^{(13)}\end{array}$ & Colombia & $\begin{array}{l}\text { Randomized controlled clinical trial without blinding. } \\
\text { Patients aged } \geq 30 \text { years who attended the Cardiovascular } \\
\text { Health Program of a hospital in Medellín, Colombia, in } \\
2010 \text {, and had a confirmed diagnosis of heart failure. The } \\
\text { intervention group consisted of } 29 \text { patients and the control } \\
\text { group of } 26 \text { patients. }\end{array}$ & $\begin{array}{l}\text { Portuguese } \\
\text { English } \\
\text { Spanish }\end{array}$ & Education \\
\hline $\begin{array}{l}\text { Article 5: Nursing care by telehealth: } \\
\text { what is the influence of distance on } \\
\text { communication?; } 2017^{(14)}\end{array}$ & Brazil & $\begin{array}{l}\text { Descriptive qualitative study with a sample of seven nurses } \\
\text { who worked in a telehealth service in Brazil. }\end{array}$ & $\begin{array}{l}\text { Portuguese } \\
\text { English }\end{array}$ & Care \\
\hline $\begin{array}{l}\text { Article 6: Telenursing manual } \\
\text { for providing care to patients } \\
\text { using clean intermittent urinary } \\
\text { catheterization; } 2017^{(15)}\end{array}$ & Brazil & $\begin{array}{l}\text { Methodological study on the construction and validation of } \\
\text { a telenursing manual. The appearance and content of the } \\
\text { manual were validated by } 11 \text { expert nurses, with validation } \\
\text { defined as a level of agreement of } 70 \% \text { among the experts } \\
\text { for each aspect of the instrument used. }\end{array}$ & $\begin{array}{l}\text { Portuguese } \\
\text { English }\end{array}$ & Care \\
\hline $\begin{array}{l}\text { Article } 7: \text { Effectiveness of a } \\
\text { telephone follow-up nursing } \\
\text { intervention in postsurgical patients; } \\
2016^{(16)}\end{array}$ & Brazil & $\begin{array}{l}\text { Quasi-experimental design with two groups conducted } \\
\text { in two hospitals in Brazil with patients undergoing a } \\
\text { gastrostomy and colectomy. The intervention group } \\
\text { consisted of } 22 \text { patients and the control group of } 21 \text { patients. }\end{array}$ & English & Care \\
\hline $\begin{array}{l}\text { Article 8: Knowledge, practice and } \\
\text { perception of nurses regarding } \\
\text { tele-nursing as a strategy for the } \\
\text { continuity of caring; } 2016^{(17)}\end{array}$ & Costa Rica & $\begin{array}{l}\text { Exploratory cross-sectional study with a convenience sample } \\
\text { of } 104 \text { nurses from a Class A public hospital in Costa Rica. }\end{array}$ & Spanish & Care \\
\hline $\begin{array}{l}\text { Article 9: The communication } \\
\text { process in Telenursing: integrative } \\
\text { review; } 2016^{(18)}\end{array}$ & Brazil & $\begin{array}{l}\text { Integrative review with selection and review of } 10 \text { articles } \\
\text { out of a total of } 128 .\end{array}$ & $\begin{array}{l}\text { Portuguese } \\
\text { English }\end{array}$ & Care \\
\hline $\begin{array}{l}\text { Article 10: Information and } \\
\text { communication technology and the } \\
\text { prevention of diseases - literature } \\
\text { review; } 2013^{(19)}\end{array}$ & Brazil & $\begin{array}{l}\text { Integrative review with selection and review of three articles } \\
\text { out of a total of } 46 .\end{array}$ & $\begin{array}{l}\text { Portuguese } \\
\text { English }\end{array}$ & Care \\
\hline $\begin{array}{l}\text { Article 11: Telehealth application } \\
\text { on the rehabilitation of children and } \\
\text { adolescents; } 20144^{(20)}\end{array}$ & Brazil & $\begin{array}{l}\text { Systematic review of randomized clinical trials on } \\
\text { telerehabilitation of children and adolescents. Twenty } \\
\text { articles were selected and reviewed out of a total of } 232 .\end{array}$ & $\begin{array}{l}\text { Portuguese } \\
\text { English }\end{array}$ & Care \\
\hline $\begin{array}{l}\text { Article 12: Nursing in Stomatherapy } \\
\text { in Telehealth UERJ: Case Studies; } \\
\text { 2014(21) }\end{array}$ & Brazil & $\begin{array}{l}\text { Case study on the development of a telehealth project in a } \\
\text { Brazilian university. }\end{array}$ & Portuguese & Education \\
\hline
\end{tabular}


Chart 2 - Objective and main results of the articles on telenursing related to the roles of care, education and management. Databases: BIREME, SciELO

\begin{tabular}{|c|c|c|}
\hline Title/Year & Objective & Main results \\
\hline $\begin{array}{l}\text { Article 1: Evaluation of } \\
\text { the training of nurses in } \\
\text { basic health units through } \\
\text { telenursing; } 2014^{(10)}\end{array}$ & $\begin{array}{l}\text { Evaluate distance } \\
\text { continuing education for } \\
\text { nursing professionals from } \\
\text { primary care units. }\end{array}$ & $\begin{array}{l}\text { Three categories emerged from the analysis: importance of the Telenursing Project for } \\
\text { care; Telenursing in the distance training process; and use of tools in the Telenursing } \\
\text { Project. According to the testimonies of the participants, this form of teaching, apart } \\
\text { from alleviating difficulties related to geographical access and reducing costs, enables } \\
\text { professionals to receive training in their own field of work, builds closeness with the } \\
\text { academy and allows for sharing of questions related to care in daily practices. }\end{array}$ \\
\hline $\begin{array}{l}\text { Article 2: Effect of a tele-care } \\
\text { model on self-management } \\
\text { and metabolic control } \\
\text { among patients with type } \\
2 \text { diabetes in primary care } \\
\text { centers in Santiago, Chile; } \\
2010^{(11)}\end{array}$ & $\begin{array}{l}\text { Evaluate the effectiveness of } \\
\text { a telephone support model } \\
\text { for self-management and } \\
\text { control of diabetes mellitus } \\
2 \text { in populations with low } \\
\text { socio-economic resources } \\
\text { in Chile. }\end{array}$ & $\begin{array}{l}\text { The perception of social health remained stable over time in the intervention group ( } p \\
=0.968) \text {, as opposed to improving in the control group }(p<0.001) \text {. Self-efficacy in the } \\
\text { intervention group increased significantly over time }(p<0.001) \text { and remained stable in } \\
\text { the control group }(p=0.107) \text {. Attendance significantly increased for the controls of the } \\
\text { Cardiovascular Health Program ( } p<0.001) \text { and was significantly higher than in the control } \\
\text { group }(p=0.002) \text {. } \\
\text { The metabolic parameters remained stable over time in the intervention group }(p=0.107) \text {; } \\
\text { on the other hand, a significant increase in the control group was noted ( }<<0.001) \text {. }\end{array}$ \\
\hline $\begin{array}{l}\text { Article 3: Imaginative } \\
\text { construction of care: } \\
\text { the nursing professional } \\
\text { experience in a remote care } \\
\text { service; } 2012^{(12)}\end{array}$ & $\begin{array}{l}\text { Understand the interaction } \\
\text { experience of health } \\
\text { professionals and users in a } \\
\text { remote care service in Chile. }\end{array}$ & $\begin{array}{l}\text { The authors presented a theoretical model which represents strategies and actions of } \\
\text { health professionals in the care of users and their families through telephone care. The } \\
\text { model emphasizes the need to study the challenges of professional communication } \\
\text { related to remote care services and how interaction is established between health } \\
\text { professionals and users by phone to provide care. }\end{array}$ \\
\hline $\begin{array}{l}\text { Article 4: Effectiveness of } \\
\text { an educational program in } \\
\text { nursing in the self-care of } \\
\text { patients with heart failure: } \\
\text { randomized controlled trial; } \\
20122^{(13)}\end{array}$ & $\begin{array}{l}\text { Evaluate the effectiveness } \\
\text { of an educational nursing } \\
\text { program for improving self- } \\
\text { care behavior in patients } \\
\text { with heart failure. }\end{array}$ & $\begin{array}{l}\text { The program included group educational meetings - telenursing sessions characterized } \\
\text { by phone calls and home visits. } 6 \% \% \text { of the control group, as opposed to } 26.6 \% \\
\text { of the control group improved their self-care score by at least } 20 \% \text { ( } p<0.001) \text {. The } \\
\text { authors recognized that it was not possible to ensure which of the activities from the } \\
\text { educational nursing intervention had a greater weight on the change in score on the } \\
\text { self-care scale and proposed that further studies be conducted along this line. }\end{array}$ \\
\hline $\begin{array}{l}\text { Article 5: Nursing care } \\
\text { by telehealth: what is the } \\
\text { influence of distance on } \\
\text { communication?; } 2017^{(14)}\end{array}$ & $\begin{array}{l}\text { Evaluate the perception } \\
\text { of nurses regarding } \\
\text { interpersonal } \\
\text { communication in } \\
\text { telehealth care. }\end{array}$ & $\begin{array}{l}\text { The perception of nurses working in telenursing was that the technology facilitated } \\
\text { their professional practices. However, as for the communication process, they felt it } \\
\text { is more difficult to communicate by telenursing, particularly due to the difficulty in } \\
\text { detecting nonverbal signs. To overcome such difficulties, they agreed that interpersonal } \\
\text { communication is a skill that should be acquired during the professional training of nurses. }\end{array}$ \\
\hline $\begin{array}{l}\text { Article 6: Telenursing } \\
\text { manual for providing } \\
\text { care to patients using } \\
\text { clean intermittent urinary } \\
\text { catheterization; } 2017^{(15)}\end{array}$ & $\begin{array}{l}\text { Elaborate and validate the } \\
\text { appearance and content } \\
\text { of a telenursing manual to } \\
\text { provide support for nurses } \\
\text { in the care of patients that } \\
\text { use a clean intermittent } \\
\text { urinary catheter. }\end{array}$ & $\begin{array}{l}\text { The telenursing manual was validated in relation to its appearance and content, } \\
\text { as evidenced by the level of agreement among the experts for each one of the } \\
\text { following aspects: Language } 97 \% \text {; Content } 97.7 \% \text {; and Objectives, Relevance, } \\
\text { Functionality and Usability - } 100 \% \text { each one. The authors reported that the creation of } \\
\text { telenursing support materials designed for patient care increases and strengthens this } \\
\text { technology, particularly in countries where its use has not been consolidated. }\end{array}$ \\
\hline $\begin{array}{l}\text { Article 7: Effectiveness of a } \\
\text { telephone follow-up nursing } \\
\text { intervention in } \\
\text { postsurgical patients; } 2016 \\
\text { (16) }\end{array}$ & $\begin{array}{l}\text { Compare the effectiveness of } \\
\text { using the telephone versus } \\
\text { conventional treatment } \\
\text { with older postsurgical adult } \\
\text { patients. }\end{array}$ & $\begin{array}{l}\text { The intervention used the telephone for following up on surgical patients in the first } \\
48 \text { hours, and four weeks and eight weeks after surgery. In the intervention group, } \\
\text { there was a lower frequency of: surgical delay }(p=0.033) \text {, reduced mobility }(p= \\
0.003) \text {, need for self-care assistance }(p=0.009) \text {, fatigue }(p=0.048) \text { and time required } \\
\text { for recovery }(p=0.048) \text { in D2. }\end{array}$ \\
\hline $\begin{array}{l}\text { Article } 8 \text { : Knowledge, } \\
\text { practice and perception of } \\
\text { nurses regarding tele- } \\
\text { nursing as a strategy for the } \\
\text { continuity of caring; } 2016^{(17)}\end{array}$ & $\begin{array}{l}\text { Determine the knowledge, } \\
\text { practices and perception of } \\
\text { nurses from Costa Rica, with } \\
\text { respect to telenursing as a } \\
\text { strategy for care continuity. }\end{array}$ & $\begin{array}{l}\text { A minority were familiar with the term "telenursing" prior to the questionnaire and } \\
\text { a majority had implemented practices related to technology. Therefore, most of the } \\
\text { people interviewed had a highly positive perspective on the topic. }\end{array}$ \\
\hline $\begin{array}{l}\text { Article 9: The } \\
\text { communication process } \\
\text { in Telenursing: integrative } \\
\text { review; } 2016^{(18)}\end{array}$ & $\begin{array}{l}\text { Identify and analyze the } \\
\text { scientific evidence on the } \\
\text { communication process in } \\
\text { telenursing. }\end{array}$ & $\begin{array}{l}\text { The technology found in the literature was communication by phone. It was noted that } \\
\text { nurses have reservations about care via phone, such as difficulty to detect nonverbal } \\
\text { communication, inadequate or misunderstood communication with consequent errors } \\
\text { in the care given, and lack of a visual reference. It was concluded that the technology } \\
\text { used for care must enable a sensation of closeness, integration, protection and safety. }\end{array}$ \\
\hline $\begin{array}{l}\text { Article 10: Information and } \\
\text { communication technology } \\
\text { and the prevention of } \\
\text { diseases - literature review; } \\
2013^{(19)}\end{array}$ & $\begin{array}{l}\text { Analyze the scientific } \\
\text { production nursing } \\
\text { care via phone contact, } \\
\text { as contributing to the } \\
\text { promotion of health and } \\
\text { prevention of diseases in } \\
\text { patients. }\end{array}$ & $\begin{array}{l}\text { Of the three articles selected, the use of the telephone in remote care focused } \\
\text { on disease, detection of complications and treatment of patients with non- } \\
\text { communicable diseases. It was concluded that telenursing should also incorporate } \\
\text { other technologies and broaden care to include promotion and education and, } \\
\text { thereby, provide comprehensive care. }\end{array}$ \\
\hline $\begin{array}{l}\text { Article } 11 \text { : Telehealth } \\
\text { application on the } \\
\text { rehabilitation of children } \\
\text { and adolescents; } 2014^{(20)}\end{array}$ & $\begin{array}{l}\text { Examine initiatives to } \\
\text { apply telehealth to } \\
\text { telerehabilitation practices } \\
\text { in children and adolescents } \\
\text { from } 0 \text { to } 18 \text { years of age, } \\
\text { based on a systematic review } \\
\text { of the literature. }\end{array}$ & $\begin{array}{l}\text { The studies demonstrated that telerehabilitation is able to produce better treatment } \\
\text { outcomes compared to traditional rehabilitation methods, resulting in lower } \\
\text { manifestation of symptoms, improved quality of life, better control over diseases and } \\
\text { higher treatment adherence. The tools used in the telerehabilitation were software, a } \\
\text { website, email and use of the telephone. }\end{array}$ \\
\hline
\end{tabular}




\begin{tabular}{|l|l|l|}
\hline Title/Year & Objective & Main results \\
\hline $\begin{array}{l}\text { Article 12: Nursing in } \\
\text { Stomatherapy in Telehealth } \\
\text { UERJ: Case Studies; } 2014 \text { (21) }\end{array}$ & $\begin{array}{l}\text { Describe the experience of } \\
\text { the authors' participation in } \\
\text { telehealth activities at the } \\
\text { State University of } \\
\text { Rio de Janeiro, Brazil. }\end{array}$ & $\begin{array}{l}\text { The authors recounted their experience in the development of an online course, within } \\
\text { the framework of a national telehealth project, for the nursing teams of primary care } \\
\text { units in Brazil, in relation to stoma patient care. The experience was successful and they } \\
\text { participated in a teleconsultation group for stomatherapy nursing. They reported that } \\
\text { teleconsultations contribute to the training of professionals and enhance care in this area. }\end{array}$ \\
\hline
\end{tabular}

\section{DISCUSSION}

Of the studies that focused on care, it stands out that only two were intervention with a quasi-experimental design. The evidence indicates that randomized controlled clinical studies are an important tool for assessing the efficacy of new health interventions and, thereby, favor their dissemination, improve the quality of care and define which interventions are the most effective in nursing practices. Despite the complexity of the design, the lack of multidisciplinary teams and shortage of time, among others, the development of randomized controlled clinical studies should be considered by nurses as an alternative for assessing care interventions ${ }^{(22-23)}$.

In terms of the technologies found in the studies, telephony was predominant as a remote information and communication technology, with a focus on non-communicable diseases. They corroborate studies that compare phone support-based telenursing interventions with normal care or in combination with normal care. A study in the United States found that telephone contact after hospital discharge reduces further hospitalizations, optimizes therapeutic control and improves post-discharge care ${ }^{(24)}$. Another American study assessed an intervention that included educational therapy sessions plus telephone contact to strengthen the coping strategies of caregivers of patients suffering from dementia, and noted an improvement in problematic behaviors of patients, as opposed to caregivers without treatment ${ }^{(25)}$.

However, the literature is more diverse regarding the use of other technologies or a combination of them. There are studies that assessed electronic surveillance by remote control using wireless blood pressure control monitors and telemonitoring (26-27); that used a web page and email combined with telephone support ${ }^{(28)}$; or that tapped into different functions of mobile technologies, including, among others, short message services, (SMS), voice calls, mobile phone applications, global positioning systems and Bluetooth ${ }^{(29-31)}$.

As for concerns about the remote communication process for providing care to people, studies have indicated the need to develop the competency of communication in nurses for telenursing practices. Authors point out that communication is an interpersonal competency and phone-base care depends on this competency due to the absence of visual contact ${ }^{(32-33)}$.

A European study that examined malpractice complaints related to a telenursing service found that failure to listen to the person calling was the most frequent reason for the complaints ${ }^{\left({ }^{(34)} \text {. Another }\right.}$ study, with a qualitative focus, which evaluated the same service with pediatric patients, found that parents want to speak first in their communication with nurses. They want to be listened to attentively before their needs are explored and their concerns alleviated ${ }^{(35)}$.

In regard to non-communicable diseases as the focus of telenursing, studies have reported that the use of information technologies and follow-up and monitoring systems improve health and self-care outcomes of people with one or more chronic diseases. Telenursing plays an important role in terms of monitoring and self-care and is considered to be a solution that enhances the quality of life of these people, in addition to reducing hospitalizations and, consequently, health system costs ${ }^{(36-37)}$. A controlled clinical study, which assessed the effect of telenursing on performing controls of patients with diabetes, found that glucose in the blood was significantly lower at the end of the study in all the preestablished measurements of the intervention group compared to the control group ${ }^{(38)}$. In addition to diabetes, children with rheumatic disease and their families have also benefited from telenursing for controlling morning pain ${ }^{(36)}$.

With respect to studies that focus on the use of telenursing in education, referred to as distance learning in the literature, it has been used in telenursing for educating patients and health professionals. A study with nursing students from the United States used telepresence technology to provide nursing care to a geriatric patient in his home. After the simulation, the students reported feeling more confident to provide care via telenursing. The authors concluded that adding telenursing to the training of future nurses would help create a safer and more adaptable workforce ${ }^{(39)}$.

In addition to training, the literature found that distance learning via telenursing should also be used for educating patients and professionals. A study conducted in Iran evaluated the effect of teaching that used a virtual social network on the knowledge and attitude of emergency room nurses in terms of disaster preparedness. A significant increase was noted in the knowledge scores of the intervention group compared to the control group, which indicates the effectiveness of learning through virtual social networks ${ }^{(40)}$.

\section{Limitations of the Study}

As for the limitations of this study, in the literature, the use of terms on the topic of telehealth is too diverse and often employed incorrectly, which justified the decision to narrow the search with the keyword "telenursing" despite perhaps restricting the selection of other publications.

\section{Contributions to the Field}

Information and communication technologies have high transformational power and their use has given rise to new work models within the health sector. Their benefits can be seen in the control of non-communicable diseases, education, and health promotion together with prevention.

Nursing as a profession has not been exempt from the influence of this new work model and is undergoing a process of change and seeking a way to combine these technological tools with the care provided to people. 
In this sense, it is necessary to know and reflect on what their role has been in the process of incorporating these technologies, especially telenursing, in the profession and how they will affect the profession in the future. Development expectations for this new type of care, education and management demonstrate that nurses must be empowered in their work and, to achieve this, must have access to information, inclusion, participation and be aware of all the emerging innovations.

This review presents the production of nurses from Latin America and the Caribbean, with a focus on telenursing since it is a technology totally within the dominion of the nursing discipline and profession. It demonstrates the need for nurses not only to be empowered but to embrace this new modality and effectively apply it in clinical practice.

\section{CONCLUSION}

Of the studies selected according to the proposed objective, it was concluded that the number of intervention studies that effectively produced knowledge that could be implemented in nursing practices was very few. There is a need to conduct studies that generate changes in care practices, whether in terms of prevention or rehabilitation, especially for major health problems that affect the population, such as cancer, cardiovascular diseases, diabetes, obesity and acquired immunodeficiency syndrome.

The predominant use of telephony - the technology focused on in the care-related studies - demonstrates that ICT use is still a challenge for Latin American nurses and that technological resources need to be explored, whether in the work context or academic training. Along the same line, in the studies that focused on education, only one used more diverse means of communication, such as video conferencing, teleconsultations and online courses.

Concerns about communication through telenursing were likewise expressed by nurses from the United States and Europe, which indicates the need for specific training for developing communication skills focused on this new mode of care.

Finally, it should be pointed out that no studies were found related to the role of management with proposals or participatory work experiences at the level of public policies or health systems management. Proposals are needed that can be innovatively and proactively applied in health organizations and that are reproducible and sustainable at the national level, and thereby benefit the population.

\section{REFERENCES}

1. Organización Panamericana de Salud. Acceso a servicios de salud integrales, equitativos y de calidad [Internet]. 2015[cited 2019 Mar 29]. Available from: https://www.paho.org/salud-en-las-americas-2017/?post_type=post_t_es\&p=311\&lang=es

2. Comisión Económica para América Latina y el Caribe (CEPAL). Desarrollo de la telesalud en América Latina Aspectos conceptuales y estado actual [Internet]. Santiago de Chile, octubre de 2013[cited 2019 Mar 29]. Available from: https://repositorio.cepal.org/bitstream/ handle/11362/35453/1/S2013129_es.pdf

3. Organización Panamericana de Salud. eSALUD OPS. Telesalud [Internet]. 2019[cited 2019 Mar 29]. Available from: https://www.paho.org/ ict4health/index.php?option=com_content\&view=article\&id=9684:telehealth\&ltemid=193\&lang=es

4. Consejo Internacional de Enfermeras (CIE). Servir a la comunidad y garantizar la calidad: Las enfermeras al frente de la Atención Primaria de Salud [Internet]. Ginebra, Suiza: CIE; 2008[cited 2019 Mar 29]. Available from: https://www.consejogeneralenfermeria.org/internacional/cie/ send/25-cie/342-02-4-da-internacional-de-la-enfermera-2008-servir-a-la-comunidad-y-garantizar-la-calidadL

5. Racionero-Torres L. Teleenfermería. Nuevo avance en el cuidado enfermero. [Tesis]. España: Universidad de Valladolid, Facultad de Enfermería; 2016.

6. Organización Panamericana de la Salud. e-Salud en Latinoamérica y el Caribe. Tendencias y Temas Emergentes [Internet]. 2013 [cited 2019 Mar 29]. Available from: http://www.ehealthstrategies.com/files/esalud_lac_ops_2003.pdf

7. González-Hoyos DM. Editorial. Hacia promoc. Salud[Internet]. 2014[cited 2019 Mar 29];19(1):9-10. Available from: http://www.scielo.org.co/ pdf/hpsal/v19n1/v19n1a01.pdf

8. Mendes KS, Silveira RC, Galvão CM. Integrative literature review: a research method to incorporate evidence in health care and nursing. Texto Contexto Enfermagem. 2008;17(4):758-64. doi: 10.1590/S0104-07072008000400018

9. International Council of Nurses. Definiciones [Internet]. 2019 [cited 2019 Mar 29];17(4):758-64. Available from: https://www.icn.ch/es/ politica-de-enfermeria/definiciones

10. Godoy SCB, Guimarães EMP, Assis DSS. Evaluation of the training of nurses in basic health units through telenfermagem. Esc Anna Nery 2014;18(1):148-155. doi.org/10.5935/1414-8145.20140022

11. Lange I, Campos S, Urrutia M, Bustamante C, Alcayaga C, Tellez A et al. Effect of a tele-care model on self-management and metabolic control among patients with type 2 diabetes in primary care centers in Santiago, Chile. Rev Med Chile 2010;138:729-37. doi: 10.4067/ s0034-98872010000600010

12. Price Romero YM, Angelo M, Muñoz Gonzalez LA. Imaginative construction of care: the nursing professional experience in a remote care service. Rev Latino-Am Enfermagem[Internet]. 2012 [cited 2019 Mar 29];20(4):[08 pantallas]. Available from: http://www.scielo.br/pdf/rlae/v20n4/es_09.pdf

13. Rodríguez-Gázquez MA, Arredondo-Holguín E, Herrera-Cortés R. Effectiveness of an educational program in nursing in the self-care of patients with heart failure: randomized controlled trial. Rev Latino-Am Enfermagem. 2012;20(2):296-306. doi: 10.1590/S0104-11692012000200012. 
14. Barbosa IA, Silva MJP. Cuidado de enfermagem por telessaúde: qual a influência da distância na comunicação? Rev Bras Enferm. 2017;70(5):928-34. doi: 10.1590/0034-7167-2016-0142

15. Souza-Junior VD, Mendes IAC, Mazzo A, Santos CA, Andrade EMLR, Godoy S. Telenursing manual for providing care to patients using clean intermittent urinary catheterization. Esc Anna Nery. 2017;21(4):e20170188. doi: 10.1590/2177-9465-ean-2017-0188

16. Santana RF, Pereira SK, Carmo TG, Freire VECS, Soares TS, Amaral DM. Effectiveness of a telephone follow up nursing intervention in postsurgical patients. Int J Nurs Pract. 2018;24:e12648. doi: 10.1111/ijn.12648

17. Carvajal FL, Vásquez VL. Conocimiento, práctica y percepción de enfermeras respecto a tele-enfermería como estrategia de continuidad del cuidado. Enfermería [Internet]. 2016 [cited 2019 Mar 29];5(2):25-33. Available from: http://www.scielo.edu.uy/pdf/ech/v5n2/v5n2a04.pdf

18. Barbosa IA, Silva KCCD, Silva VA, Silva MJP. The communication process in Telenursing: integrative review. Rev Bras Enferm[Internet]. 2016[cited 2019 Mar 29];69(4):765-72. Available from: http://www.scielo.br/pdf/reben/v69n4/en_0034-7167-reben-69-04-0765.pdf

19. Lachtermacher AP, Tocantins FR. Information and communication technology and the prevention of diseases: literature review. Rev Pesqui: Cuid Fundam. 2013;5(4):424-30. doi: 10.9789/2175-5361.2013v5n4p424

20. Santos MTN, Moura SCDO, Gomes LMX, Lima AH, Moreira RS, Silva CD, et al. Telehealth application on the rehabilitation of children and adolescents. Rev Paul Pediatr. 2014;32(1):136-43. doi: 10.1590/S0103-05822014000100020

21. Souza NVDO, Scherlowski HM, David L, Mauricio VC, Costa CCP. Nursing in Stomatherapy in Telehealth UERJ: case Studies. J Bras Tele [Internet]. 2014[cited 2019 Mar 29];3(2):70-2. Available from: https://pesquisa.bvsalud.org/portal/resource/pt/sus-32231

22. Caparó FL, Soto FL. The importance of Clinical Research. Horiz Med[Internet]. 2016[cited 2019 Mar 29];16(1): 4-5. Available from: http:// www.scielo.org.pe/pdf/hm/v16n1/a01v16n1.pdf

23. Medina EU, Riveros ER, Pailaquilén RMB. Clinical trials for Evidence-Based Nursing: a possible challenge. Acta Paul Enferm. 2011;24(3):41925. doi:10.1590/S0103-21002011000300018

24. Kind AJ, Jensen L, Barczi S, Puentes A, Kordahl R, Smith MA, Asthana S. Lowcost transitional care with nurse managers making mostly phone contact with patients cut rehospitalization at a VA hospital. Health Aff (Millwood). 2012;31(12):2659-68. doi: 10.1377/hlthaff.2012.0366

25. Mills M, Loney P, Jamieson E, Gafni A, Browne G. A primary care cardiovascular risk reduction clinic in canada was more effective and no more expensive than usual on-demand primary care a randomised controlled trial. Health Soc Care Community. 2010;18(1):30-40. doi: 10.1111/j.1365-2524.2009.00872.x

26. Bosworth HB, Powers BJ, Olsen MK, McCant F, Grubber J, Smith V et al. Home blood pressure management and improved blood pressure control: results from a randomized controlled trial. Arch Intern Med 2011; 171 (13): 1173-1180. doi:10.1001/archinternmed.2011.276

27. Domingo M, Lupón J, González B, Crespo E, López R, Ramos A, et al. Telemonitorización no invasiva en pacientes ambulatorios con insuficiencia cardiaca: efecto en el número de hospitalizaciones, días de ingreso y calidad de vida. Estudio CARME (Catalan Remote Management Evaluation). Rev Esp Cardiol. 2011;64 (4):277-85. doi: 10.1016/j.recesp.2010.10.032

28. Appel LJ, Clark JM, Yeh HC, Wang NY, Coughlin JW, Daumit G et al. Comparative Effectiveness of Weight-Loss Interventions in Clinical Practice. N Engl J Med 2011;365:1959-68. doi: 10.1056/NEJMoa1108660

29. Vollmer WM, Owen-Smith AA, Tom JO, Laws R, Ditmer DG, Smith DH et al. Improving adherence to cardiovascular disease medications with information technology. Am J Manag Care[Internet] 2014[cited 2019 Mar 29];20(SP17):SP502-SP510. Available from: https://www.ncbi.nlm. nih.gov/pmc/articles/PMC6358176/pdf/nihms967099.pdf

30. Fang R, Li X. Electronic messaging support service programs improve adherence to lipid-lowering therapy among outpatients with coronary artery disease: an exploratory randomised control study. J Clin Nurs. 2016;25:664-71. doi: 10.1111/jocn.12988

31. Khonsari S, Subramanian P, Chinna K, Latif LA, Ling LW, Gholami O. Effect of a reminder system using an automated short message service on medication adherence following acute coronary syndrome. Eur J Cardiovasc Nurs. 2015;14:170-9. doi: 10.1177/1474515114521910

32. Valanis BG, Gullion CM, Moscato SR, Tanner C, Izumi S, Shapiro SE. Predicting patient follow-through on telephone nursing advice. Clin Nurs Res. 2007;16(3):251-69. doi: 10.1177/1054773807303055

33. Snooks H, Williams A, Griffiths L, Peconi J, Rance J, Snelgrove S, et al. Real nursing? the development of telenursing. J Adv Nurs. 2008;61(6):631-40. doi: 10.1111/j.1365-2648.2007.04546.x

34. Ernesäter A, Winblad U, Engström M, Holmström IK. Malpractice claims regarding calls to Swedish telephone advice nursing: what went wrong and why? J Telemed Telecare. 2012;18(7):379-83. doi: 10.1258/jtt.2012.120416

35. Kaminsky E, Carlsson M, Röing M, Holmström IK. If I didn't trust Swedish Healthcare Direct, I would never call-views of making pediatric health calls. Clin Nurs Stud. 2013;1(3):57-69. doi: 10.5430/cns.v1n3p57

36. Ramelet AS, Fonjallaz B, Rio L, Zoni S, Ballabeni P, Rapin J, et al. Impact of a nurse led telephone intervention on satisfaction and health outcomes of children with inflammatory rheumatic diseases and their families: a crossover randomized clinical trial. BMC Pediatr. 2017;17(1):168. doi: 10.1186/s12887-017-0926-5

37. Shany T, Hession M, Pryce D, Roberts M, Basilakis J, Redmond, S et al. A small-scale randomised controlled trial of home telemonitoring in patients with severe chronic obstructive pulmonary disease. J Telemed Telecare. 2017;23(7):650-6. doi: 10.1177/1357633X16659410

38. Kotsani K, Antonopoulou V, Kountouri A, Grammatiki M, Rapti E, Karras S et al. The role of telenursing in the management of Diabetes Type 1: a randomized controlled trial. Int J Nurs Stud. 2018;80:29-35. doi: 10.1016/j.jinurstu.2018.01.003 
39. Lister M, Vaughn J, Brennan-Cook J, Molloy M, Kuszajewski M, Shaw RJ. Telehealth and telenursing using simulation for pre-licensure USA students. Nurse Educ Pract. 2018;29:59-63. doi: 10.1016/j.nepr.2017.10.031

40. Ghezeljeh TN, Aliha JM, Haghani H, Javadi N. Effect of education using the virtual social network on the knowledge and attitude of emergency nurses of disaster preparedness: a quasi-experiment study. Nurse Educ Today. 2019;73:88-93. doi: 10.1016/j.nedt.2018.12.001 